\title{
Use of E-Money and Debit Cards in Student Consumption Behavior
}

\author{
Dewi Fatmasari 1,*, Waridin², Akhmad Syakir Kurnia ${ }^{2}$, and Rizaldi amin $^{3}$ \\ ${ }^{1}$ Student at Department of Economics, Faculty of Economics and Business, Universitas Diponegoro, Indonesia \\ ${ }^{2}$ Department of Economics, Faculty of Economics and Business, Universitas Diponegoro, Indonesia \\ ${ }^{3}$ Department of Syariah Banking, Faculty of Sharia and Islamic Economics, IAIN Syekh Nurjati Cirebon, Indonesia
}

\begin{abstract}
IAIN Sharia Banking Student Sheikh Nurjati consumes high students, but in conducting transactions students are less in utilizing electronic money and debit card facilities in daily activities so that the problem is how the e-money and e-money are used. the use of debit cards against student consumption expenses. This system of payment transactions using electronic money and debit cards will affect a person's behavior in spending or consumption behavior. This study aims to investigate the use of e-money and debit cards in consumption expenditures and how it affects the consumption expenditure. This research applied a quantitative method by using a questionnaire as an instrument to collect the data. Further, the data were then analyzed by applying multiple linear regression models. As result, it was revealed that partially using emoney in students' consumption behavior had a negative and an insignificant influence, while using debit cards had a positive and significant influence on students' consumption behavior. Thus, based on the F test results, it is proved that using e-money and debit cards together have a significant impact on students' consumption behavior.
\end{abstract}

Keywords: electronic money (e-money), debit cards, consumption behavior.

\section{Introduction}

Transaction benefits can be seen from how an efficient payment system with minimal costs. In addition, the issuance of low transaction costs will make payment service users choose payment services that have relatively low prices. Therefore, a decrease in transaction costs and speed of transactions will make the non-cash payment system more effective through electronic payment innovations [1]. Payment systems have an important role in community consumption activities, namely activities to spend income or income for various types of goods or services in meeting human needs. The most important human needs to be fulfilled in consumption activities are basic needs. Community consumption can be grouped into food and non-food consumption [2].

The creation of e-money is to help consumers to transact more easily [3]. The use of e-money also has benefits, including payment transactions becoming faster and more efficient, safer, encouraging better personalization of banking services [4]. As for non-cash payments other than money electronic money known as debit cards, debit cards are present in advance of electronic money (E-Money). Debit card is a payment card issued by a bank and can be used to make payments for user obligations in a transaction or in economic activities, one of which is a shopping transaction. According to Bank Indonesia (2018) Where a debit card can function as a substitute for payment with debit card cash refers to the user's saving balance at the issuing bank.

With non-cash payments such as electronic money (e-money) and debit cards, not only increase efficiency in regulating lifestyle but also make life patterns more consumptive. Debit cards and electronic money that is used by students can affect student's consumption behavior because it increases efficiency in transactions and makes someone easier to spend their money on economic activities [5].

With the increasing amount of electronic money circulating and also the increasing number of electronic money infrastructure in Indonesia, this can increase the level of use or electronic money transactions, here are data on the number of electronic money transactions in 2014-2018.

\footnotetext{
* Corresponding author: dewifatmasari73@gmail.com
} 
Table 1. Number of Electronic Money Transactions for 2014-2018

\begin{tabular}{|c|c|c|}
\hline $\begin{array}{c}\text { Period } \\
\text { Volume }\end{array}$ & $\begin{array}{c}\text { Value } \\
\text { (Transaction) }\end{array}$ & $\begin{array}{c}\text { Nominal in } \\
\text { million } \\
\text { (Rupiah) }\end{array}$ \\
\hline Year 2014 & 203.369 .900 & 3.319 .556 \\
\hline Year 2015 & 535.579 .528 & 5.283 .018 \\
\hline Year 2016 & 683.133 .352 & 7.063 .689 \\
\hline Year 2017 & 943.319 .933 & 12.375 .469 \\
\hline Year 2018 & 2.922 .579 .528 & 5.283 .018 \\
\hline \multicolumn{2}{|l}{} \\
\hline \multicolumn{2}{|l}{} \\
\hline
\end{tabular}

In the Table 1, it is seen that electronic money transactions in 2014-2018 period have increased both from its value and volumes. This proves that using noncash payment system (e-money) is increasingly gaining trust from the public to use electronic money in conducting transactions.

Research conducted (Runnemark et al, 2015) [9] explains that non-cash payments using debit cards can affect someone to pay more in transactions, meaning that the level of one's consumption expenditure will increase, with payments using debit cards, with a non-cash transaction system having a positive effect on public consumption because of public consumption increases. Ramadani (2016) [22] notes the use of debit cards and emoney has a significant effect on students' consumption behavior. However, based on a survey conducted on Islamic Banking students of IAIN Sheikh Nurjati Cirebon where the level of consumption of students is high, in conducting transactions students are less in utilizing electronic money and debit card facilities on daily activities, so that the problem is how to influence the use of e-money and debit card against student consumption expenses.

\section{Literature Review}

The payment system is a regulation, a standard, and an instrument used in the process of exchanging financial values carried out by two parties or more. Whereas, Law of Bank Indonesia No. 23/1999 defines the payment system as a system involving a set of regulations, agencies, and ways used in transferring funds to fulfill the economic activity obligations. Thus, it is a system that has a set of regulations used to establish more efficient transactions including transferring funds carried out by one party to another in order to fulfill the economic activity obligations.

Electronic money is money used by employing electronic means. In general, the transaction uses a computer network. Electronic money is money that has a value stored in electronic media, where the value of emoney will decrease when consumers use it for payment [6]. While electronic money in the transaction payment system is also known as a debit card, debit cards are electronic cards issued by banks as a facility for savings or current account holders that can be used for various banking transactions at ATM machines and shopping at stores that have Electronic Data friction machines Capture (EDC). The use of debit cards directly reduces funds from savings or checking accounts [7].

This payment transaction system using electronic money and debit cards will affect a person's behavior in spending or consuming. Consumption is defined as an activity of spending the value of goods and services. Consumption has a broad understanding of the goods and services needed to meet human needs. Consumable goods derive from disposable items and items that are more than disposable. Household consumption expenditure is an expenditure to buy various types of needs at a certain time carried out by households. Household consumption expenditure is the largest component of actual expenditure [8]. In the study of Runnemark [9], it was explained that non-cash payments using debit cards can affect someone to pay more in transactions, meaning that the level of one's consumption expenditure will increase with payment using a debit card [9]. Community consumption affects the non-cash transaction system and has a positive effect because users of public consumption increase every year and can affect the non-cash payment system as a payment facility. Technological developments followed by increased consumption have a considerable influence on the new consumption structure which prioritizes perspectives from external goods to obtain recognition and representation as a factor of modern society, the presumption which is then embedded in non-cash transactions to prove that consumption is a factor of efforts to strengthen the superiority of the community class and to maintain group relations [10]. One's consumption pattern is formed in adolescence, namely the transition period where habits will affect consumption. At this time, habits begin to form. The adolescents' unstable nature forces them to use goods or services that are less rational which is influenced by advertising, media, imitating friends and wasteful tendencies.

According to Rustam, et al (2015) [5], this consumptive behavior causes excessive use of money by teenagers like students which results in increasing level of students' consumption expenditure. Runnemark (2015) [9], In their study proves that the influence of payment methods plays an important role in consumers' willingness to pay for products. Explains that e-money plays a greater role in relatively small countries, in terms of economy [11]. On the other hand, in large economies, e-money shows little significance, besides Schut argues the main advantages of the Diary of Consumer Payment Choice are 1) the ability to measure expenditures with payment instruments combined into solid purchases 2 ) relatively low load, and 3) effective retrieval [12]. And research explains that electronic cash using smart cards is replaced by electronic cash based on mobile payments that use smartphones to be used as a means of payment for various transactions within an organization. in organizations [13]. 


\section{Method}

This research applied a quantitative research approach by using questionnaire as an instrument used to collect the data. The total population is 799 students of Islamic Banking IAIN Sheikh Nurjati Cirebon, and by using the Slovin formula obtained a sample of 89 students. The variables in this study are Electronic Money, namely payment instruments in electronic form where the value of money is stored in certain electronic media. Debit Cards are payments that use cards that can be used to make payments for obligations arising from economic activity (Bank Indonesia, 2018). Consumption Behavior is an act of using final goods and services that are ready for human use to meet their needs [14]. The analytical method used is multiple linear regression, namely $\mathrm{Y}=\mathrm{a}$ $+\mathrm{b} 1 \mathrm{X} 1+\mathrm{b} 2 \mathrm{X} 2+\mathrm{e}$, where $\mathrm{Y}$ is Student Consumption Behavior, Constant $\mathrm{X} 1$ is the use of e-money and $\mathrm{X} 2$ is the Use of Debit and e-Cards is Error.

\section{Discussion}

The effect of using electronic money (x1) and debit cards (x2), on student consumption expenditures (y) can be seen using multiple linear regression analysis with the following results:

Table 2. Multiple Linear Regression Test Results

\begin{tabular}{|c|c|c|c|c|}
\hline Model & $\boldsymbol{\beta}$ & $\begin{array}{c}\text { Std. } \\
\text { Error }\end{array}$ & $\mathrm{t}$ & Significance \\
\hline Constant & 0,352 & 3,111 & 0,113 & 0,910 \\
$\mathrm{X} 1$ & $-0,068$ & 0,109 & $-0,617$ & 0,539 \\
$\mathrm{X} 2$ & 0,373 & 0,070 & 5,291 & 0,000 \\
\hline $\mathrm{R}=$ & & & & \\
0,505 & & & & \\
$\mathrm{R}^{2}=0$, & & & & \\
255 & & & & \\
F-hit & & & & \\
$=14,744$ & & & & \\
\hline
\end{tabular}

Based on the research that has been done, the results obtained from the hypothesis which shows partial X1 (Electronic Money) prove negative and not significant towards student consumption safety. This is indicated by the variable regression coefficient using electronic money of -0.068 , with a $\mathrm{t}$ count of $-0.617 \leq \mathrm{t}$ table of 1.986 and a significance value of $0.539 \geq 0.05$, then $\mathrm{H}_{0}$ is accepted and $\mathrm{H}_{\mathrm{a}}$ is rejected. Thus, the results prove that this study proves negative for student consumption behavior. The more students use electronic money, the less consumption of students, and vice versa the fewer students use electronic money, the greater the consumption of students, then based on the results of research and research on research on student consumption using electronic money is still limited in use and limited use of shopping facilities those who use electronic money, are still contributing to spending facilities that still use cash, so that around a very limited number of students live only in a few places. The same related research is that attitudes or behaviors do not affect the interest to use electronic money in payments [15].

This research is reinforced by previous researchers who have been conducted by Schuh [12] which shows that non-cash payment systems (electronic money) do not have a significant effect but are negative because they can reduce the burden of higher payments so that consumption expenditure is more efficient, electronic money is in great demand not only because ease of transaction but also promos and other benefits obtained . Then this is also supported by research conducted by Adiyanti [6] in his research showing that good promotional attractiveness can influence user interest in transacting using e-money. Thus, e-money is a choice in transactions but does not significantly affect student consumption expenditure [16].

The results showed that partially X2 (debit card) had a significant positive effect on student consumption behavior. This is indicated by the regression coefficient of debit card usage of 0.373 , with a $\mathrm{t}_{\text {count }}$ of $5.291 \geq \mathrm{t}$ table of 1.986 and a significance value of $0.000 \leq 0.05$, so $\mathrm{H}_{0}$ is accepted and $\mathrm{H}_{\mathrm{a}}$ is rejected. The results indicate that debit cards influence student consumption behavior and have positive relationships. The more students use debit cards, the more student consumption expenses, and vice versa, the fewer students use debit cards, the fewer student consumption behavior. This indicates that students feel the benefits and ease of using transactions using debit cards because debit cards basically provide convenience in shopping and the number of promos or discounts so that consumption behavior increases.

According to the calculation of the coefficient of determination shows that the use of electronic money and debit cards has an effect of 25.55 percent while 74.45 percent is influenced by other variables not examined. Based on the F test, it shows that the result of F count is 14,744 with a significance level of $0,000 \leq$ 0.05 , so it can be concluded that the use of electronic money and debit cards simultaneously or jointly has a significant effect on consumption behavior. Consumption reflects the value incurred to meet daily needs and is an important factor in managing personal finance. This is consistent with the research conducted which is consistent with this research in which simultaneously using e-money and debit cards had a positive impact on students' consumption behavior. Previous researchers, Runnemark [9], showed that debit cards significantly and positively affect consumption expenditures, making it an attractive choice as a means of payment. Another study that non-cash payments (debit cards) affect consumption significantly and positively, therefore payment instruments are important in influencing consumption levels. Other studies also revealed that payments using debit cards and e-money will also affect the currency demand in Indonesia, so this will increase the consumption behavior of Indonesian people [17]. The structure of payments and payment systems in a country consists of two forms, namely cash and non-cash payments [18]. According to another study said that with the existence of consumer payment transaction facilities more comfortable, ease in accessing each payment transaction, such as credit cards that 
facilitate consumers in consumption expenditure and even unexpected consumption expenditures [19, 20, 21].

\section{References}

1. J. Snellman and J. Vessala, Forecasting the electronification of Payments with Learning Curves, Bank of Finland Discussion Paper. 8/99 (1999)

2. Dumairy, Perekonomian Indonesia, Yogyakarta, Bagian Penerbit Erlangga (1999)

3. Indriastuti. M. \& Wicaksono. R, Influencers, EMoney in Banking Sector, South East Asia Journal of Contemporary Business, Economics and Law, 4(2), 10-17, (2014)

4. Seetharama. A. \& Rudolph Ra. J, An Empirical Study on the Impact of Earnings per Share on Stock Prices of a Listed Bank in Malaysia, The International Journal of Applied Economics and Finance, 5(2),114-126, (2011)

5. Rustam. A., Widya. Y,. Rukhviyanti. N, Pengaruh Minat Individu terhadap Penggunaan Mobile Banking (m-Bankimg) : model kominasi tecnology acceptance model (tam) dan theory of planned behavior (TPB), Jurnal Informatika dan Sistem Informasi, 7(1). ISSN 2085-8795, (2015)

6. Adiyanti. A. I, Pengaruh Pendapatan, Manfaat, Kemudahan Penggunaan, Daya Tarik Promosi, dan Kepercayaan Terhadap Minat Menggunakan Layanan E-Money (Studi Kasus: Mahasiswa Universitas Brawijaya), Jurnal Ilmiah. 1-13. (2015)

7. Powell. S., Electronic data capture. Chemistry \& Industry, (11), 21-22. (2004)

8. Hasmarini. M. I, Analisis Konsumsi di Indonesia Tahun 1989-2002 (Tinjauan Terhadap Hipotesis Keynes dan Post Keynes), Ekonomi Pembangunan, 6, 143-162. (2005)

9. Runnemark. E., Hedman, J. \& Xiao. X, Do consumers pay more using debit cards than cash? Electronic Commerce Research and Applications, 14(5),285-291, ( 2015)

10. Nelasari. P. R. \& Cahyono. H, Pengaruh Sistem Transaksi Non Tunai Terhadap Tingkat Konsumsi Masyarakat Di Surabaya, 1, 165-171, (2018)

11. Soseco. T, Effect of e-Money to Economic Performance (a comparative study of selected countries) effect of e-money to economic performance (a comparative study of selected countries ), Federal Reserve Bank of Boston, 2-17. (2017)

12. Schuh. S, Measuring Consumer Expenditures With Payment Diaries, Economic Inquiry, 56(1), 13-49. (2017)

13. Kim. H. J., Lee. S. J, \& Shin. I. C, Design and implementation of in-house electronic money using java cards, International Journal of Smart Home, 7(5),103-114, (2013)
14 Soediyono, Ekonomi Mikro (Kedua), Jakarta: Erlangga, (1989)

15. Nugroho A., Najib. M \& Simanjuntak. M, Factors Affecting Consumer Interest in Electronic Money Usage with Theory of Planned Behavior (TPB), Journal of Consumer Sciences, 3(1) 15-27 ISSN 2460-8963, (2018)

16. Parastiti. D. E., Mukhlish. I \& Haryono. A, Analisis Penggunaan Uang Elektronik pada Mahasiswa Fakultas Ekonomi Universitas Negeri Malang (studi kasus uang elektronik brizzi), Jurnal Ekonomi dan Pembangunan Universitas Negeri Malang, 7(1) ISSN 2502-7115, (2015)

17. Siwinastiti. L \& Nirmala. T, Analisis Pengaruh Penggunaan Alat Pembayaran menggunakan Kartu (APMK) dan Uang Elektronik terhadap Permintaan Uang Kartal di Indonesia, Jurnal Ekonomi Pembangunan, 3(2), 195-210 ISSN 23029595, (2014)

18. Hancock. D. \& Humprey. D.B, Payment Transacsion, Instrument and System, Journal of Banking \& Finance, 2(11), pp 1573-1624 (1998)

19. Pulina. M, Consumer Behavior in The Credit Market : a banking case study, International Journal of Consumer Studies, 35(1), pp 86-94, (2011)

20. Soman. D, Effects of Payment Merchanism on Spending Behavior: the role of rehearsaland immediacyof payments. Journal of Consumer Research, 27(4), pp. 460-474 (2001)

21. J. Srivastava \& P. Raghubu, Monopoly Money the Effect of PaymentCoupling and Form on Spending Behaivor, Journal of Experiental Psycology Applied, 14(3), pp 213-225, (2008)

22. L. Ramadani, Pengaruh Penggunaan Kartu Debit dan Uang Elektronik (E-Money) terhadap Perilaku Konsumsi Mahasiswa, Jurnal Ekonomi dan Studi Pembangunan, 8(1), 1-8 (2016) 